\section{Morphological and physiological characteristics in vitro anthurium plantlets exposed to silicon}

\author{
Gabrielen de Maria Gomes Dias ${ }^{1^{*}}$, Joyce Dória Rodrigues \\ Soares ${ }^{2}$, Suelen Francisca Ribeiro ${ }^{3}$, Adalvan Daniel Martins ${ }^{2}$, \\ Moacir Pasqual ${ }^{2}$ and Eduardo Alves ${ }^{4}$
}

\begin{abstract}
The objective was to evaluate morphological and physiological differences in anthurium plants in vitro, with the use of silicon added to the culture medium. Nodal segments were inoculated in Pierik with different sodium silicate concentrations $\left(0.0,0.5,1.0\right.$ or $\left.2.0 \mathrm{mg} \mathrm{L}^{-1}\right)$. After 100 days in a growth room, phytotechnical characteristics were evaluated, physiological concentrations of silicon, photosynthetic pigments and microanalysis X-ray. A higher yield of chlorophyll $a$ and $b$, was observed in plants supplemented with $2.0 \mathrm{mg} \mathrm{L}^{-1}$ of sodium silicate. Anthurium plants showed better growth development with an increase in the number of leaves, dry weight and length of the aereal part in plants supplemented with 0.5 and $2.0 \mathrm{mg} \mathrm{L}^{-1}$ sodium silicate. It was also observed an increase in the number of roots of plants supplemented with $1.0 \mathrm{mg} \mathrm{L}^{-1}$ of sodium silicate. The use of sodium silicate in culture medium improves the quality of plantlets with an increased absorption of nutrients in the plant Anthurium.
\end{abstract}

Key words: Anthurium andraeanum, growth, development, sodium silicate.

\section{INTRODUCTION}

Anthurium is currently considered to be a product of great business potential in domestic and foreign floriculture markets. Anthurium is prized not only for its natural beauty and the color structure of its flowers, but also for its high durability topost-harvest (Junqueira and Peetz 2012).

Several studies have been conducted using Anthurium tissue culture to evaluate the potential of obtaining plantlets using this method. In general, the most important factor has been the cultivar specificity, resulting in the need to develop micropropagation protocols unique to each genotype (Gantait and Mandal 2010).

Puchoa (2005) observed that, in general, researchers working with tissue culture have found a wide variation in the responses obtained in vitro when using different genotypes of anthurium. Consequently, adjustments in the culture medium are essential for obtaining vigorous plants of commercial quality.

The mineral elements that stimulate the growth of plants and that are essential for only a few plant species or under specific conditions are considered beneficial elements (Furlani 2004). These elements are important for the normal growth and development of some plants, but their absence is not considered a limiting factor. One of the elements considered to be beneficial is silicon (Korndörfer 2006).
Crop Breeding and Applied Biotechnology 17: 18-24, 2017 Brazilian Society of Plant Breeding. Printed in Brazil http://dx.doi.org/10.1590/198470332017v17n1a3

.


Although silicon is not considered to be an essential element, the benefits of using this element in agriculture are being increasingly recognized by researchers worldwide. For example, the use of silicates in agriculture, in addition to direct effects on productivity, can a significant contribute in the enhancement and, consequently, reduce the use of pesticides (Reis et al. 2008). The structural role of silicon (Si) in the cell wall can increase the concentrations of hemicellulose and lignin, increasing the rigidity of the cell (Camargo et al. 2007).

Studies on the effects of silicon applied to the in vitro cultivation of floriculture segments are still quite limited. The most recent studies examining the role of Si have been performed in flowers with post-harvest and production, such as calla (Almeida et al. 2009), rose (Locarno et al. 2011), gerbera (Guerrero et al. 2012), chrysanthemum (Carvalho-Zanao et al. 2012, Sivanesan et al. 2013) and ornamental sunflower (Carvalho et al. 2009, Oliveira et al. 2013). The only work examining the role of $\mathrm{Si}$ in ornamental plants grown in vitro has been performed in orchids (Soares et al. 2011, Soares et al. 2012). Despite the wide variety of ornamental plants grown commercially, relatively few species have been evaluated for their potential for silicon absorption (Frantz et al. 2010).

Considering the benefits observed for other species, the effect of silicon on the development of plants grown in vitro needs to be assessed, particularly for species with commercial importance, such as anthurium. The present study aimed to evaluate the use of silicon on the growth of Anthurium andraeanum cv. Rubi plants in vitro and to evaluate the morphological and physiological characteristics of the leaves when using concentrations of sodium silicate.

\section{MATERIAL AND METHODS}

Nodal segments of Anthurium andraeanum cv. Rubi plantlets established in vitro were inoculated in Pierik solution (Pierik 1976) supplemented with $30 \mathrm{~g} \mathrm{~L}^{-1}$ sucrose and solidified with $1.8 \mathrm{~g} \mathrm{~L}^{-1} \mathrm{Phytagel}^{\mathrm{TM}}$. Sodium silicate $\left(\mathrm{Na}_{2} \mathrm{SiO}_{3}\right) \mathrm{was}$ added to the culture medium at the following concentrations: $0.0,0.5,1.0$ and $2.0 \mathrm{mg} \mathrm{L}^{-1}$. The $\mathrm{pH}$ of the culture medium was adjusted to 5.8 , and the culture medium was then autoclaved at $121^{\circ} \mathrm{C}$ and $1.2 \mathrm{~atm}$ for 20 minutes.

Subsequently, in a laminar flow hood, nodal segments were inoculated in $400 \mathrm{~mL}$ flasks containing $50 \mathrm{~mL}$ of culture medium and the different sodium silicate concentrations. The vials were maintained in a growth chamber with a photoperiod of 16 hours at $25 \pm 2{ }^{\circ} \mathrm{C}$ temperature, with a light intensity of $52.5 \mu \mathrm{mol} \mathrm{m} \mathrm{m}^{-1}$. After 100 days, we evaluated the parameters described below:

Phytotechnical features - evaluated all experimental plantlets by observing the number of leaves, the number of roots, the length of the aereal part $(\mathrm{cm})$, the fresh and dry weights of the shoots $(\mathrm{g})$, the root length $(\mathrm{cm})$ and the fresh and dry weights of the roots $(\mathrm{g})$. The dry weight of the plant material was evaluated after drying in an oven at $60^{\circ} \mathrm{C}$ temperature for 72 hours or until a constant weight was obtained.

Chlorophyll contents - The contents of chlorophyll $a, b$ and the total chlorophyll contents were quantified according to the method described by Arnon (1949). For this purpose, leaves were collected from 10 plants per treatment, and $0.1 \mathrm{~g}$ of leaf tissue was macerated in liquid nitrogen and placed in $80 \%$ acetone. The material was then centrifuged at $8,000 \times \mathrm{g}$ for 15 minutes, the supernatant was collected and diluted to $25 \mathrm{ml}$, and the absorbance was measured in a spectrophotometer at $663 \mathrm{~nm}$ and $645 \mathrm{~nm}$. The pigment content was calculated as described by Lichtenthaler (1987).

Silicon concentration - leaves were collected from 12 plants, dried in a forced-circulation oven at $60^{\circ} \mathrm{C}$ temperature to a constant weight and ground separately. The determination of silicon by the molybdenum-blue colorimetric method was performed according to the methodology proposed by Gallo and Furlani (1978).

X-ray microanalysis - samples from the middle third of the second sheet of three plants were fixed in Karnovsky solution (Karnovsky 1965), dehydrated in increasing concentrations of acetone (30\%, $50 \%, 70 \%, 90 \%$ and $100 \%$ ) and then subjected to critical point drying, using liquid $\mathrm{CO}_{2}$ as a transition medium (Robards 1978). The samples were subsequently coated with carbon and analyzed using a Baltec CED 020 LEO-EVO 40 scanning electron microscope, following the protocol described by Alves and Perina (2012).

Experimental design and statistical analyses - The experimental design was completely randomized, with four treatments consisting of 15 vials that each contained 2 explants. The data were subjected to analyses of variance and to regression analyses, with $p<0.05$, using the software SISVAR (Ferreira 2011). 


\section{RESULTS AND DISCUSSION}

The concentrations of sodium silicate applied to the Pierik culture medium affected anthurium seedling growth in vitro. As demonstrated in Figure 1, there was a significant effect of the sodium silicate concentration on the number of leaves, the length of the aereal part, the number of roots and the dry weight of the shoots. Increasing concentrations of sodium silicate appeared to behave quadratically, with the peak of the function indicating the increased production of sheets up to the estimated concentration of $0.7 \mathrm{mg} \mathrm{L}^{-1}$ and further increases in the concentration of sodium silicate resulting in a marked decrease in the number of leaves. Similar results were also observed by Braga et al. (2009) working with strawberry in vitro. However, unlike the results of the present study, Pasqual et al. (2011), working with orchids in vitro, found a greater number of sheets with the use of calcium silicate. Moreover, Asmar et al. (2011), working with in vitro banana, and Oliveira et al. (2013), working with ornamental sunflower, found no differences in the number of leaves when applying sodium silicate and calcium.

With increasing concentrations of sodium silicate, a linear increase in the length of the aerial part of anthurium was observed, with plants treated with the concentration of $2.0 \mathrm{mg} \mathrm{L}^{-1}$ achieving the maximum length of $1.82 \mathrm{~cm}$ (Figure 1). For Asmar et al. (2011), the use of sodium silicate provided the largest shoot growth for in vitro banana. Pasqual et al. (2011) obtained higher length of the aereal part for in vitro orchids using $2.0 \mathrm{mg} \mathrm{L}^{-1}$ calcium silicate.

The dry mass of the aerial part of the plant demonstrated a quadratic increase according to increase in the concentration of sodium silicate. The maximum yield was estimated at the concentration of $1.4 \mathrm{mg} \mathrm{L}^{-1}$ sodium silicate (Figure 1). Similarly, Almeida et al. (2009) and Sivanesan et al. (2013) reported that different concentrations of silicon promoted increased dry matter in the aerial parts of the chrysanthemum and chrysanthemum plants. Asmar et al. (2011), working with in vitro banana, reported higher shoot dries mass when using sodium silicate in the culture medium.

A larger number of roots were observed in plants supplemented with $1.0 \mathrm{mg} \mathrm{L}^{-1}$ sodium silicate, with a quadratic response observed for this concentration, followed by a sharp decline in root numbers for plants treated with higher concentrations of sodium silicate (Figure 1). Similar results were observed by Soares et al. (2008) when they worked with sodium silicate in the acclimatization of orchids.

The decrease in the number of roots observed in plants cultivated in higher concentrations of sodium silicate may stem from the fact that any nutrient taken in excess can cause a nutritional imbalance in the plant, including silicon. In
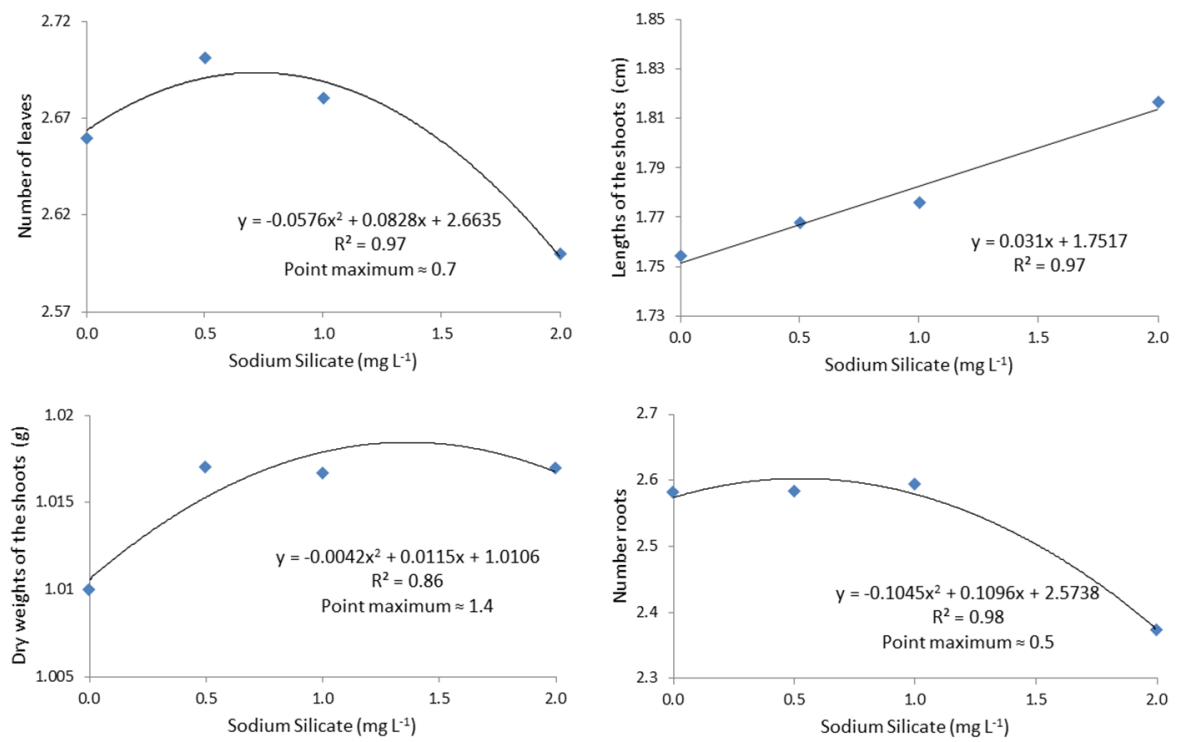

Figure 1. Phytotechnical features in Anthurium andraeanum cv. Rubi plantlets after 100 days in culture with different concentrations of sodium silicate. 

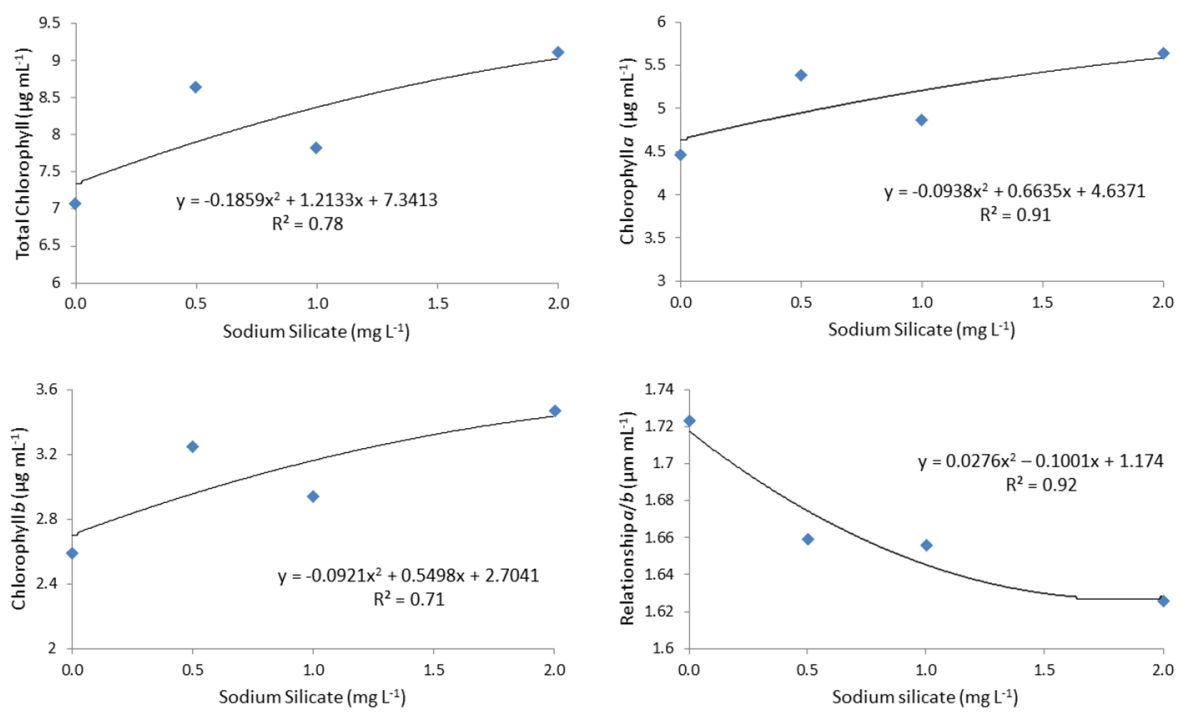

Figure 2. Chlorophyll $a$ and $b$ contents, total chlorophyll and $a / b$ ratio in the leaves of Anthurium andraeanum cv. Rubi plantlets grown for 100 days in vitro in a culture medium containing sodium silicate.

studies of mineral nutrition, it is necessary to consider the nutrients as a whole because, in the process of absorption, one nutrient can exert influence over other nutrients, given the possible interactions that may occur (Malavolta et al. 1997).

It can be observed in Figure 2 that there is an increasing trend in the levels of chlorophyll $a$ and $b$ and total chlorophyll levels with increasing concentrations of sodium silicate, and the best result was obtained with $2.0 \mathrm{mg} \mathrm{L}^{-1}$ sodium silicate. The highest levels of chlorophyll $b$ were observed in the control, which was culture medium without the addition of silicon, followed by decreasing levels with increasing concentrations of sodium silicate.

The results of the present study demonstrated the effectiveness of using silicon on the chlorophyll content of anthurium, similar to the data reported by Gong et al. (2005), Sousa et al. (2010), Locarno et al. (2011) and Sivanesan et al. (2013). These results are likely due to silicon being associated with the maintenance of photosynthesis, the chlorophyll distribution and the protection and preservation of the structural and functional deterioration of cell membranes (Agarie et al. 1998). Increased chlorophyll content with silicon supplementation was also observed by Al-Aghabary et al. (2005) in tomato plants.

The silicon content in the leaves of anthurium was significantly influenced by the concentrations of sodium silicate used. As shown in Figure 3, there was a proportional increase in the concentration silicon in the leaves of anthurium plantlets at higher concentrations of sodium silicate. The highest concentration was estimated to occur at $1.5 \mathrm{mg}$ $\mathrm{L}^{-1}$ sodium silicate, with a quadratic response to increasing concentrations.

In general, plants are considered to be silicon accumulating plants if they have foliar silicon levels greater than $1 \%$ and are considered to be non-accumulating plants if they have foliar silicon levels lower than $0.5 \%$ (Ma et al. 2001). Although anthurium are monocotyledonous plants, they are classified as non-accumulative for silicon $(0.23$ to $0.40 \%$ ) (Figure 3 ). Similar results were also observed by Almeida et al. (2009) when working with silicon in the mineral nutrition of calla. Thus, anthurium plantlets have no

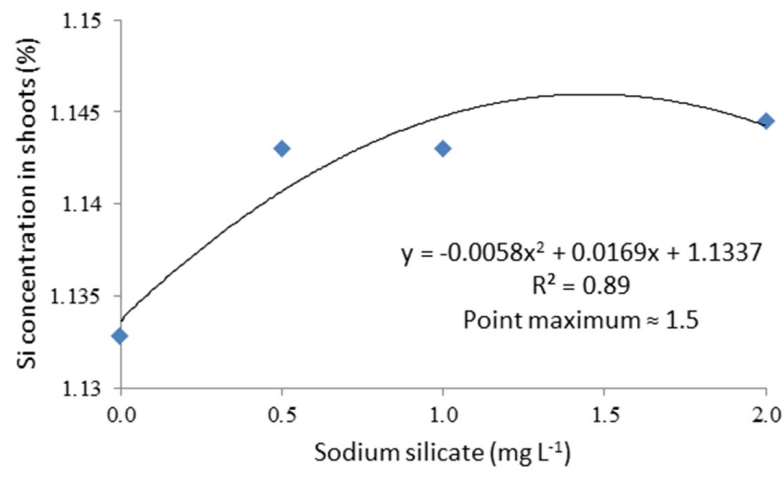

Figure 3. Silicon concentrations in shoots of Anthurium andraeanum cv. Rubi cultured in vitro for 100 days. 


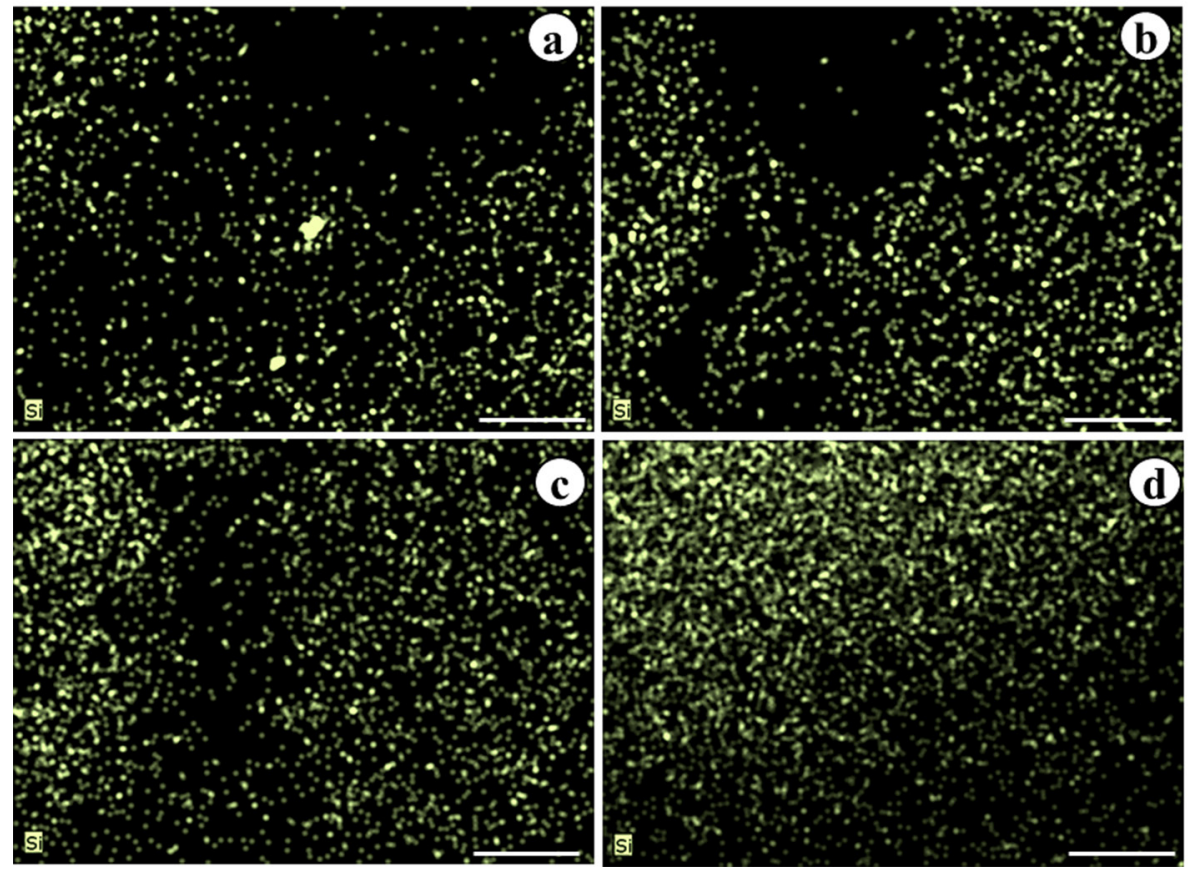

Figure 4. Mapping of Si on the abaxial epidermis of leaves from Anthurium andraeanum cv. Rubi plantlets cultured in vitro for 100 days, demonstrating the presence and the evolution of the distribution of silicon with increasing concentrations of sodium silicate in the culture medium. a) Control, b) $0.5 \mathrm{mg} \mathrm{L}^{-1}$, c) $\left.1.0 \mathrm{mg} \mathrm{L}^{-1}, \mathrm{~d}\right) 2.0 \mathrm{mg} \mathrm{L}^{-1}$. Bar $=20 \mu \mathrm{m}$.

ability to accumulate silicon in shoots at high concentrations but can benefit from this element even in small quantities.

The presence of silicon in the control can be explained by the fact that silicon is an abundant element in nature that is present everywhere, even on water and its amount varies according to the region (Luz et al. 2006, Larezzini and Bonotto 2014). Si identified in the treatments without sodium silicate likely originated from the water used during the experiment that, although deionized, contained some neutral forms of Si that could not be completely eliminated. However, it is noteworthy that Si was absorbed in insignificant amounts in the control when compared to treatments receiving sodium silicate.

In the X-ray microanalysis (MAX), Si was found on the abaxial side of leaves treated with sodium silicate. Detection of Si was observed in all treatments, including the control. The data confirm the chemical analysis of the leaves, which also identified the presence of silicon in all treatments.

When mapping was performed for silicon (Si), there was an evolutionary distribution related to the concentration of sodium silicate applied to the culture medium (Figures $4 \mathrm{~B}, \mathrm{C}$ and D). The presence of $\mathrm{Si}$ in the control was also detected during mapping of the abaxial side of the leaf (Figure $4 A$ ).

The polymerization of silicon on the lower surface of the sheet, termed the silicification process, is common in grasses (Lux et al. 2002) and may occur as observed in the dicotyledonous coffee (Pozza et al. 2004). Previously, there have been no reports in the literature regarding the deposition of $\mathrm{Si}$ in anthurium. The MAX demonstrated that $\mathrm{Si}$ is positioned primarily in the epidermis because, when observed in cross-section, the Si levels in the sheet appeared much lower than in the control.

\section{CONCLUSIONS}

Levels of photosynthetic pigments were higher when plants of Anthurium andraeanum cv. Rubi were grown in culture medium supplemented with $2.0 \mathrm{mg} \mathrm{L}^{-1}$ of sodium silicate. 
The use of sodium silicate in culture medium improves the quality of plantlets with an increased absorption of nutrients in the plant Anthurium andraeanum cv. Rubi.

\section{ACKNOWLEDGEMENTS}

We thank the Coordination of Improvement of Higher Education Personnel (CAPES) for funding, and the National Council for Scientific and Technological Development (CNPq) for granting the scholarship.

\section{REFERENCES}

Agarie S, Agata W and Kaufman PB (1998) Involvement of silicone in the senescence of Rice leaves. Plant Production Science 1: 104-105.

Al-Aghabary K, Zhujun Z and Qinhua S (2005) Influence of silicon supply on chlorophyll content, chlorophyll fluorescence, and antioxidative enzyme activities in tomato plants under salt stress. Journal of Plant Nutrition 27: 2101-2115.

Almeida EFA, Paiva PDO, Carvalho JG, Oliveira NP, Fonseca J and Carneiro DNM (2009) Efeito do silício no desenvolvimento e na nutrição mineral de copo-de-leite. Revista Brasileira de Horticultura Ornamental 15: 103-113.

Alves $\mathrm{E}$ and Perina FJ (2012) Apostila do curso introdutório à microscopia eletrônica de varredura e microanálise de raios-X. UFLA/FAEPE, Lavras, 63p.

Arnon DI (1949) Copper enzymes in isolates choroplasts. Polyphenoloxidade in Beta vulgaris. Plant Physiology 24: 1-15.

Asmar AS, Pasqual M, Rodrigues FA, Araujo AG, Pio LAS and Silva SO (2011) Fontes de silício no desenvolvimento de plântulas de bananeira 'Maçã' micropropagadas. Ciência Rural 41: 1127-1131.

Braga FT, Nunes CF, Favero AC, Pasqual M, Carvalho JG and Castro EM (2009) Anatomical characteristics of the strawberry seedlings micropropagated using different sources of silicon. Pesquisa Agropecuária Brasileira 44: 128-132.

Camargo MS, Korndörfer GH and Pereira HS (2007) Solubilidade do silício em solos: influência do calcário e ácido silícico aplicados. Bragantia 66: 637-647.

Carvalho PC, Júnior LAZ, Grossi JAS and Barbosa GB (2009) Silício melhora produção e qualidade do girassol ornamental em vaso. Ciência Rural 39: 2394-2399.

Carvalho-Zanao MP, Júnior LAZ, Barbosa JG, Grossi JAS and Ávila VT (2012) Yield and shelf life of chrysanthemum in response to the silicon application. Horticultura Brasileira 30: 403-408.

Ferreira DF (2011) SISVAR: a computer statistical analysis system. Ciência \& Agrotecnologia 35: 1039-1042.

Frantz JM, Locke JC, Sturtz DS and Leisner S (2010) Silicon in ornamental crops: detection, delivery and function. In Rodrigues FA (ed) Silício na agricultura. UFV, DPF, Viçosa, p. 111-134.

Furlani AMC (2004) Nutrição mineral. In Kerbauy GB (ed) Fisiologia vegetal. Guanabara Koogan, Rio de Janeiro, p. 40-75.

Gallo JR and Furlani PR (1978) Determinação de silício em material vegetal pelo método colorimétrico do azul de molibdênio. Bragantia 37: 5-11.

Gantait S and Mandal N (2010) Tissue culture of Anthurium andraeanum: a significant review and future prospective. International Journal of Botany 6: 207-219.

Gong HJ, Zhu XY, Chen KM, Wang SM and Zhang CC (2005) Silicon alleviates oxidative damage of wheat plants in pots under drought. Plant Science 169: 313-321.

Guerrero AC, Fernandes DM and Ludwig F (2012) Acúmulo de nutrientes em gérbera de vaso em função de fontes e doses de potássio. Horticultura Brasileira 30: 201-208.

Junqueira AH and Peetz MS (2012) Comercialização de antúrios no Brasil: aspectos relevantes dos mercados interno e externo. In Castro ACR, Terao D, Carvalho ACPP and Loges V (eds) Antúrio. Embrapa, Brasília, p. 163.

Karnovsky MJ (1965) A formaldehyde-glutaraldehyde fixative of high osmolality for use in eletron microscopy. Journal of Cellular Biology 27: 137-138.

Korndörfer GH (2006) Elementos benéficos. In Fernandes MS (ed) Nutrição mineral de plantas. SBCS, Viçosa, p.355-374.

Larezzini FT and Bonotto DM (2014) O silício em águas subterrâneas do Brasil. Ciência e Natura 36: 159-168.

Lichtenthaler HK (1987) Chlorophylls and carotenoids: pigment photosynthetic biomembranes. Methods in Enzymology 148: 362-385.

Locarno M, Fochi CG and Paiva PDO (2011) Influência da adubação silicatada no teor de clorofila em folhas de roseira. Ciência e Agrotecnologia 35: 287-290.

Lux A, Luxova M, Hattori T, Inanaga S and Sugimoto Y (2002) Silicification in sorghum (Sorghum bicolor) cultivars with different drought tolerance. Physiologic Plantarum 115: 87-92.

Luz JMQ, Guimarães STMR and Korndörfer GH (2006) Produção hidropônica de alface em solução nutritiva com e sem silício. Horticultura Brasileira 24: 295-300.

Ma JF, Miyake $Y$ and Takahashi E (2001) Silicon as a beneficial element for crop plant. In Datnoff LE, Korndörfer GH and Snyder G (eds) Silicon in agriculture. Elsevier Science, New York, p. 17-39.

Malavolta E, Vitti GC and Oliveira AS (1997) Avaliação do estado nutricional das plantas. Princípios e aplicações. $2^{\text {nd }}$ edn, POTAFOS, Piracicaba, 319p.

Oliveira JTL, Campos VBC, Chaves LHGC and Guedes Filho DH (2013) 


\section{GMG Dias et al.}

Crescimento de cultivares de girassol ornamental influenciado por doses de silício no solo. Revista Brasileira de Engenharia Agrícola e Ambiental 17: 123-128.

Pasqual M, Soares JDR, Rodrigues FA, Araujo AG and Santos RR (2011) Influência da qualidade de luz e silício no crescimento in vitro de orquídeas nativas e híbridas. Horticultura Brasileira 29: 324-329.

Pierik RLM (1976) Anthurium andraeanum Lindl. Plantles produced from callus tissues cultivated in vitro. Physiologia Platarum 37: 80-82.

Pozza AAA, Alves E, Pozza EA, Carvalho JG, Montanari M, Guimarães PTG and Santos DM (2004) Efeito do silício no controle da cercosporiose em três variedades de cafeeiro. Fitopatologia Brasileira 29: 185-188.

Puchoa D (2005) In vitro mutation breeding of anthurium by gamma radiation. International Journal of Agriculture \& Biology 7: 11- 20.

Reis THP, Figueiredo FC, Guimarães PTG, Botrel PP and Rodrigues CR (2008) Efeito da associação silício líquido solúvel com fungicida no controle fitossanitário do cafeeiro. Coffee Science 3: 76-80.

Robards AW (1978) An introduction to techniques for scanning electron microscopy of plant cells. In Hall JL (ed) Electron microscopy and cytochemistry of plant cells. Elsevier, New York, p. 343-444.

Sivanesan I, Son MS, Song JY and Jeong BR (2013) Silicon supply through the subirrigation system affects growth of three chrysanthemum cultivars. Horticulture, Environment, and Biotechnology 54: 14-19.

Soares JDR, Pasqual M, Rodrigues FA, Villa F and Carvalho JG (2008) Adubação com silício via foliar na aclimatização de um híbrido de orquídea. Ciência \& Agrotecnologia 32: 626-629.

Soares JDR, Pasqual M, Rodrigues FA, Villa F and Araujo AG (2011) Fontes de silício na micropropagação de orquídea do grupo Cattleya. Acta Scientiarum Agronomy 33: 503-507.

Soares JDR, Pasqual M, Araujo AG, Castro EM, Pereira FJ and Braga FT (2012) Leaf anatomy of orchids micropropagated with different silicon concentrations. Acta Scientiarum Agronomy 34: 413-421.

Sousa JV, Rodrigues CR, Luz JMQ, Carvalho PC, Rodrigues TM and Brito CH (2010) Silicato de potássio via foliar no milho: fotossíntese, crescimento e produtividade. Bioscience Journal 26: 502-513. 